\title{
NONCONDITIONED GSR TO AUDITORY STIMULI AND ITS APPLICATION TO AUDIOMETRY
}

\author{
By \\ MASAOMI SHIMODAIRA
From the Department of Otolaryngology, Faculty of Medicine, Shinshu University, Matsumoto (Director: Prof. T. Suzuki)

The appearance of nonconditioned GSR to pure tone stimuli and its evaluation to the practical application in objective audiometry was studied. Endosomatic method was used for measuring the GSR, and all responses were recorded graphically.

The results were as follows.

1. Galvanic adaptation to repeated pure tone stimuli took place rapidly.

a) As auditory stimuli, $1000 \mathrm{cps}$ pure tone at $80 \mathrm{db}$ were presented. Among three groups of which time interval of stimuli were $20 \mathrm{sec}$., $40 \mathrm{sec}$, and 1 minut, respectively, it seemed that galvanic adaptation tended to appear more slowly as time interval became longer, however, there was no statistically significant correlation.

b) As auditory stimuli, $1000 \mathrm{cps}$ pure tone were presented at 20 sec. interval of stimuls. Among four groups of which intensity of stimuli were 10 $\sim 20 \mathrm{db}, 30 \sim 40 \mathrm{db}, 50 \sim 60 \mathrm{db}$ and $80 \mathrm{db}$ respectively, a relationship was not established between the rapidity of galvanic adaptation and the intensity of stimuli.
2. Nonconditioned GSR to pure tones was very unstable and different iudividually, however, if a subject concentrated his attention on the test tone, his GSR became stable, and its threshold value obtained with GSR was markedly lowered.

Subjects were previously instructed to count the number of times that he could hear test tone, in order to concentrate his attentation on test stimuli.

3. Threshold determination with GSR audiom. etry were performed on 71 subjects by means of the method mentioned above.

As test tones, $500 \mathrm{cps}, 1000 \mathrm{cps}, 2000 \mathrm{cps}$, and 4000 cps pure tones were used in $10 \mathrm{db}$ step ascending method. GSR andiometry proved possible for 59 cases out of 71 subjects, and $90 \%$ of the threshold value of obtained with GSR audiometry was distributed within $\pm 10 \mathrm{db}$ with those obtained in stand. ard audiometry.

4. This audiometric method was difficult to apply in the measurement of hearing acuity of young children under 4 years of age.

\section{音刺激による無条件皮膚電気反応* (nonconditioned GSR) とその聴力測定への応用}

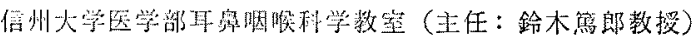

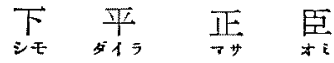

第1章 序言

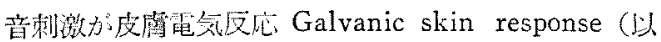
下 GSR と略記与る）在諨発する好適空刺游の1つであ る事は，Féré ${ }^{10)}$, Tarchanoff ${ }^{37}$ ) の研究以来上く矨ら扎

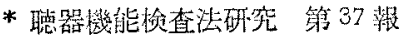

ている事迟であつて，この現象を他覚的聴力測定に応用 せんとする陚み梳古くからなされてきた。しかしなが ら，純音は GSR を発現せしめるには刺激効果に乏し く，閔值附近の強さでは反応を起し難い事が多く，且反

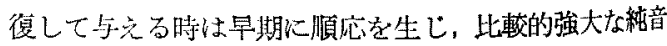
刺激に対しても反応の急激な減票，消失をさたして，测 
日耳自下平二音刺激による無条件皮盧電気反応 (nonconditioned GSR) とその聴力测定への応用 65一1067

定は不能となる等の欠点を有する. 従つて音刺激により 直接出現する GSR（無条件反応）を指䅺とする聴力测 定即ち simple or nonconditioned GSR audiometry を純音聴力閾值の測定に利用する事は殆ど不能と見做さ れてきた。

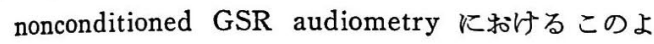
らな障碍を打破する方法として, 1949 年来 Bordley, Hardy 等は GSR を指標とし, 純音を条件刺激, 電 気刺激を無条件刺激とする条件反射を利用した測定方法 (conditioned GSR audiometry) を用いて聴力湘定を 陚み，優れた成績を発表した3４４１5)16). 以来この方法 による多数の追試が行われ，現在 GSR audiometry 之 云えぱこの conditioned GSR audiometry を指寸かの 感がある。

しかし1948年 Doerfler ${ }^{8)}$ は nonconditioned GSR audiometry により, 自覚閾値と殆ど差のないオージオ グラムを作る事に成功した旨発表した，彼の報告は唯1 例てついての成績であるが，測定に当つては簡単な装置 を用いて被検者の 注意力を音刺激に 集中させる事によ り，純音に対する GSR の不安定性，順応を克服したと 述へ，被検者の精神的緊張の調整のいかんが本法による 測定成績に大きな影響を与兄る事を示唆した。

私は純音刺激に対する GSR の発現状態を種々なる条 件の下に観察し, 無条件反応として現われる GSR が他 覚的聴力測定法として利用できるか否かを検討すべく下 記の実験を行つた。

\section{第 2 章 実 験 計 画}

\section{I. 刺激音の反復呈示に対する順応の現われ力}

A. 純音刺激間隔の長短と順応 $(1000 \mathrm{cps}, 80 \mathrm{db})$

(1) 刺激間隔 20 秒

(2) 刺激間隔 40 秒

(3) 刺激間隔 1 分

B. 複合音の反復と順応(牛の鳴声の擬音, $80 \mathrm{db}$, 間隔 20 秒)

C. 音刺激の強さと順応 $(1000 \mathrm{cps}$, 間隔 20 秒, 刺 激時間約 1 秒)

(1) 闇值上 $10 \sim 20 \mathrm{db}$

(2) 䦪值上 $30 \sim 40 \mathrm{db}$

(3) 闖值上 $50 \sim 60 \mathrm{db}$

D. 同 1 例に対して A-(1)の検查を経口的 (3日間 隔で 4 回) に繰返した場合の反応の消長

【、音刺激に対少る被檢者の精神的負荷の有無と反応 閔值 (1000cps 純音, $10 \mathrm{db}$ step 上算法)
A. 被㭘者に負何を与えた場合（聴えた音を数えさ せる)

B. 負荷を与えない場合（無作為に音をきかせる）

III. GSR 㥁力測定 (nonconditioned GSR audiometry)
A. 成人正常聴力例
B. 成人難聴例
C. 小児正常聴力例
D. 小昌高度難聴例

\section{I. 実 験 室}

第 3 章 実験方法

測定は全て電磁的にシールドされた防音室で行つた。 GSR 增幅器, 記録器, オージオメータ一等の装置は隣 接する部屋に置かれ, 両室間の連絡, 応答のためにイン ターフォンが, 又防音室内の钼察のために両室問の隔壁 に小硝子空が設けられてある. 更に防音室には寒冷期で も室温を $20^{\circ} \mathrm{C}$ 以上に保つために暖房器を倩えた。

\section{GSR 堌幅器及び記録器}

GSR は三栄測器製 MPA-203 型万能記争器を用いて 電位法で測定し, 反応は全て記録紙上に記録した。本装 置は前置增幅器, 主增幅器及びペン書き記録器よりな り, 前置增幅器は双極誘導による差動增幅方式を, 主增 幅器は直流增幅方式を採つている. 前置增幅器の時定数 は3 秒とし, 堌幅度は入力電圧 $1 \mathrm{mV}$ に対して記録器の ペンの振れがほぶ $2 \mathrm{~mm}$ となる上う調節し，記録緍の

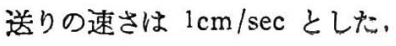

\section{III. 磷導 電極}

GSR 誘導電極は手掌に，不関電極は前膊の手関節に 近い手掌傊に固定した、雨者共に銀製で，前者は直徍 $2 \mathrm{~cm}$ の円板, 後者は $5 \mathrm{~cm} \times 3 \mathrm{~cm}$ （小児では $2 \mathrm{~cm} \times 2.5$ $\mathrm{cm} ）$ の方形である. 電極踝は用いず，極板をガーゼで

\section{第 1 図電極の装着}

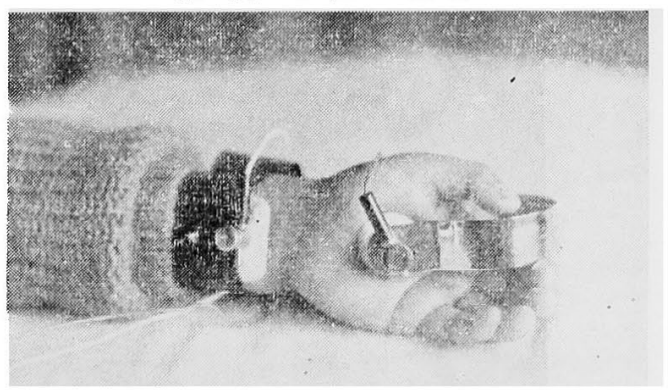


覆い，これに高濃度食塩水を浸して使用した．電極の固 定には手掌部は金属性の固定器を, 新膊部はゴムバンド

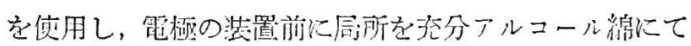
清拭した (図 1).

\section{IV. 音 源}

音源としては紹部及び複合音を使用した，前背として は Yoshinox 49-Bオージオメーターを用い, イヤホー ンを介して音を与党た。後者には牛の擬音を伐用し，擬 音笛より録音テープに録音したものを減衰器を通して間 值上 $80 \mathrm{db}$ の強さで与克た。な抗こ机等の部刺激が被众

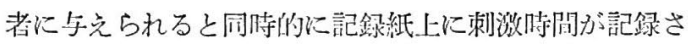
れるよらにした。

\section{V. 実験材料}

実験の対異は医学部の学生, 看護学校の生徒並びに当 科の患者の中より迩び，総林197例に対して上述の㫦画 に従つて测定した，小兒砟を除いて，乙の年令層は13

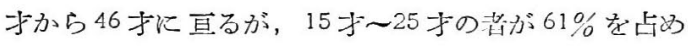

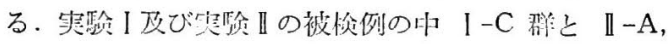

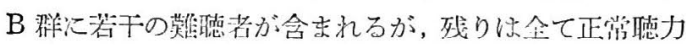
者である。实驗 III-D の高度難聴児は，松本市内の㑭 学校の低学年兒童の中から, 前年度に行つた聴力检查の

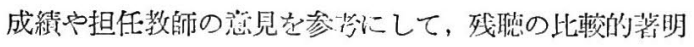
な者を選えだ。

\section{VI. 測定時の一般的注意事項}

榆笨に際しては，被愉者は椅子に坐らせ，雨手を前の

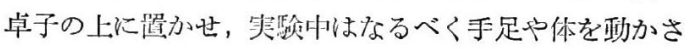

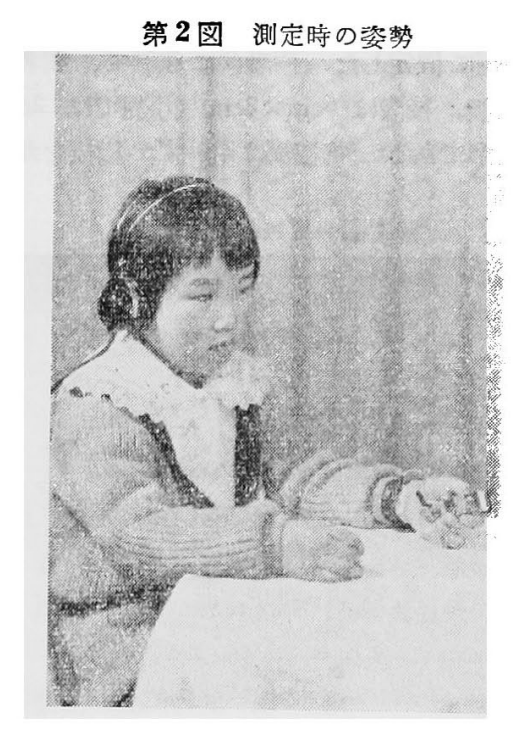

ぬように注意を与克た（図2），測定に 臨んで大切な事 は，被愉者の精神的安定を得る事である，被検者が不安 や疑惧の念走抱いていると自発性反応が頻発し，記録紙 上の基線が安定するのに時間を要する事があり，特沉小 児ではこの傾向が強い、故に予めこの检査についてなん 等の心配むない哥を被検者に充分納得させ，実験の中途 でも必要に応じて附添人や同室の助手を通じて同様の旨 の祱得を行い，なるべく短時間の中に検查を終了しなけ れぱならない.しかしながら種々の手掔を講しても甚線 の安定しない例もあり，これは笑臨刘象より除外した。

\section{VII. 測定方法}

検查以全て 1 例 1 耳について行い, GSR 測定後直り に自覚的間值を测定した.

实験 I 群では最大刺激回数を 10 回とし，仮令早期化 反応が消失しても更に 2,3 回音刺激を繰返し与克て反応 出現の有惩を碓めた，又測定に入る前に予め刺湤音を聞

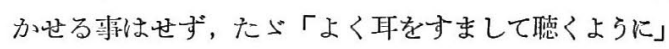

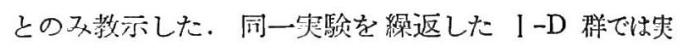

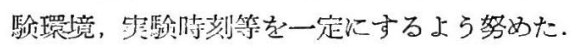

实験』硼では音刺激は閾值下と思われる強さより 10 $\mathrm{db}$ step 上年法で与兄, 刺湤持繶洔間はほડ゙ 1 秒, 问隔 は 20 秒乃至 40 秒とした. I-A 吪に対しては，予め2, 3 種類の純音を短時問に次々聞かせ，「この種の音が間 隔をおいて段々強々聞壳てくるから, 何回聴劣たか数觉 て榆者に報らせるように」と教觉，反応が現わ扎始めて からも更に 20〜30db 强い点まで音刺激を与兄て, 反 応出現の状態を钼察した、【ーB 群仗対しては予め何の 教示も与光ず 80db の強さまで刺激音を聞かせた. 又 GSR 测定後行つた自覚間値の測定も $10 \mathrm{db}$ step 上昨 洁によつた。

III群の被检者に対しては II-A 群に和けると网㥞の 指示を与点，同様の方法で測定した. $1000 \mathrm{cps}, 2000 \mathrm{cps}$, $4000 \mathrm{cps}$, $500 \mathrm{cps}$ の順に反応閾值を測定したが，1音の

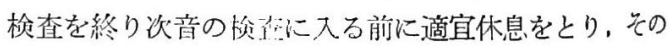
間に上記の教示を繰返して与えた。

\section{VIII. 判定基準}

記録紙上に得られた反応曲線が与克られた音刺澈によ るものか否かの判定は潜伏时問及び波形の 2 つより

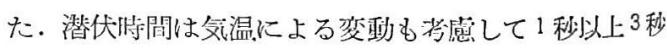
以内のものを採り，波形については，電位法で測定した

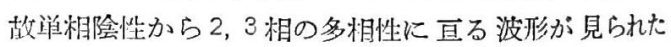

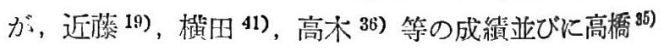
による波形の分類を参教にした. 又所謂（士）と思わ扎 


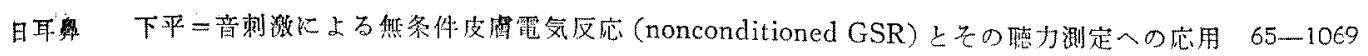

る反応は総て唅て，確実に（+）のるの小文採つた。 私の行つた筷験では雷極間の抵抗 (resistance level) 土大多数が $40 \mathrm{~K} \Omega$ 以内であつ大が，例外的に $60 \mathrm{~K} \Omega \sim$ ○ 0 $\Omega$ 以上の值走示す例があり，この上うな例は強大 音剩激に対して子㱠と゚反応を示さ奴故，実歌対象より 狳外した。

\section{第 4 章 実娩成 繢}

\section{I. 刺激音の反復呈示に対する順応の現われ方}

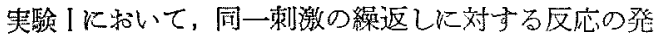

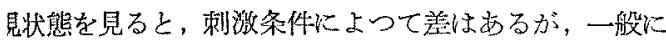

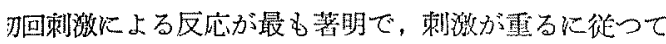
急速に順応を示して反応は漸减し，遂には全く消失し ここの傾向は純音を用いた時は特汇顕著で，初回剌激 つ双反応し，その後は全く反応しない例当少くなく， 匡少数ながら始めから全く反応しない例もあつた，以 下実験項目に従つて成績䘮述べる。

A. 紽音剩激間隔の長短子順応

被検者を了碓比分ち， $1000 \mathrm{cps} 80 \mathrm{db}$ の純音をそれぞ $\imath 20$ 秒 (30 例)，40 秒 (11 例)，1 分 (12 例)の間隔で F克反応の回数を見た，その成績は表 1 《示卞如く，無 视例は 20 秒群似 2 例あつたの夕で， 3 群の合計 53 例 751 例 (96.3\%) が少くとも初回刺激に性反灾した。 元均反応回数江表に見る如く刺激間隔が長い、群程多くな ;㑯向が覬觉るが，推計学的には有意差はなからた。

第 1 表 実験 I-A

刺激問隔上反応回数（刺溦音 $1000 \mathrm{cps}$ 純音, $80 \mathrm{db}$ )

\begin{tabular}{|c|c|c|c|}
\hline 反底回数 & 20 秒 & 40 秒 & 1 分 \\
\hline ○回 & 2 例 & O例 & O例 \\
\hline 1 & 9 & 2 & 0 \\
\hline 2 & 7 & 4 & 3 \\
\hline 3 & 3 & 1 & 1 \\
\hline 4 & 2 & 1 & 6 \\
\hline 5 & 2 & 0 & 1 \\
\hline 6 & 2 & 0 & 1 \\
\hline 7 & 1 & 1 & 0 \\
\hline 8 & 1 & 2 & 0 \\
\hline 9 & 1 & 0 & 0 \\
\hline 10 & 0 & 0 & 0 \\
\hline 䌊 例 数 & 30 & 11 & 12 \\
\hline $\begin{array}{l}\text { 平均反灾 } \\
\text { 回 数 }\end{array}$ & 2,9回 & 3.6 回 & 3.7国 \\
\hline
\end{tabular}

第 2 表 実験 I-B

牛の鳴声 $(80 \mathrm{db})$ 飞 $1000 \mathrm{cps}, 80 \mathrm{db}$ 純望汇対与る反応回数の比䡋

\begin{tabular}{|c|c|c|}
\hline 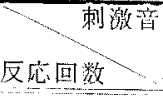 & 牛の喝声 & $\begin{array}{l}1000 \mathrm{cps} \\
\text { 紨 }\end{array}$ \\
\hline 0 回 & O例 & 2例 \\
\hline 1 & O & 9 \\
\hline 2 & 0 & 7 \\
\hline 3 & 0 & 3 \\
\hline 4 & 1 & 2 \\
\hline 5 & 3 & 2 \\
\hline 6 & 3 & 2 \\
\hline 7 & 0 & 1 \\
\hline 8 & 0 & 1 \\
\hline 9 & 1 & 1 \\
\hline 10 & 2 & 0 \\
\hline 総 例 数 & 10 & 30 \\
\hline $\begin{array}{l}\text { 承的区怎 } \\
\text { 回 }\end{array}$ & 6.6 回 & 2.9回 \\
\hline
\end{tabular}

B. 複合音の反復と順灾

被榆例は10 例で，その成縝は表 2 に示した如く，全 例が 4 回以上反応した。こ机に対して $1000 \mathrm{cps}$ 純音を 同一条件 (80db，間隔 20 秒) で与兊た A-(1) 群では 4 回以上反応したものは 30 例中 11 例に過ぎず，平均反応 回数毛前者が 6.6 国であるのに対して後者は 2.9 回であ クその差は推計学的にも存意であった。この成續は擬音 に上る刺激效果が純音に比して著しく大きい高，即ち純 音が刺激効果に乏しい事宗している。

C. 音剩激の強さ之㮌心

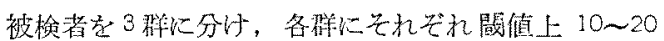
$\mathrm{db}(12$ 例)，30 40db (11 例)，50 $60 \mathrm{db}$ (11例) の強 さの音を与兄て反応回数を見九，艺の成續は表 3 亿示声

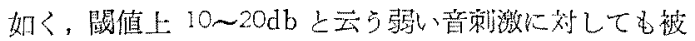
榆例の全てが初回刺激に反応を示した（图3）。雨にこ

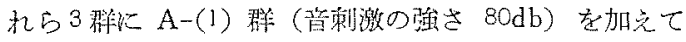
音の強さと反応回数の関倸老見ると，网表に示与上らに

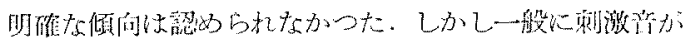

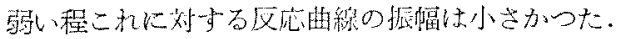

D. 同 1 例に対して A-(1) の众查を絽日的に繰返 した場今の反応の棌展

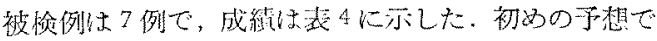

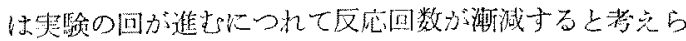

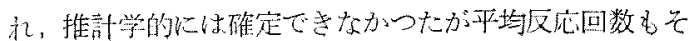


第 3 表 实鏊 I-C

音刺激の強さと反応回数 ( $1000 \mathrm{cps}$ 純音)

\begin{tabular}{|c|c|c|c|c|}
\hline $\begin{array}{l}\text { 音制嘚の } \\
\text { 反庒回数 }\end{array}$ & $10 \sim 20 \mathrm{db}$ & $30 \sim 40 \mathrm{db}$ & $50 \sim 60 \mathrm{db}$ & $80 \mathrm{db}$ \\
\hline 0 回 & O例 & 2例 & O例 & 2例 \\
\hline 1 & 9 & 3 & 7 & 9 \\
\hline 2 & 2 & 1 & 3 & 7 \\
\hline 3 & 1 & 2 & 0 & 3 \\
\hline 4 & 0 & 2 & 0 & 2 \\
\hline 5 & 0 & 0 & 0 & 2 \\
\hline 6 & 0 & 1 & 0 & 2 \\
\hline 7 & 0 & 0 & 1 & 1 \\
\hline 8 & 0 & 0 & 0 & 1 \\
\hline 9 & 0 & o & 0 & 1 \\
\hline 10 & 0 & 0 & 0 & 0 \\
\hline 棇 例 数 & 12 & 11 & 11 & 30 \\
\hline $\begin{array}{l}\text { 平均 反底 } \\
\text { 回 }\end{array}$ & $1.3[\mathrm{~g}]$ & 2.3回 & 1.8回 & 2.9回 \\
\hline
\end{tabular}

第3図 $1000 \mathrm{cps}$ 純音の反得星示飞詨寸る反出出現 の状態, 测激時間䄪 1 秒, 刺湟間㼨 20 秒

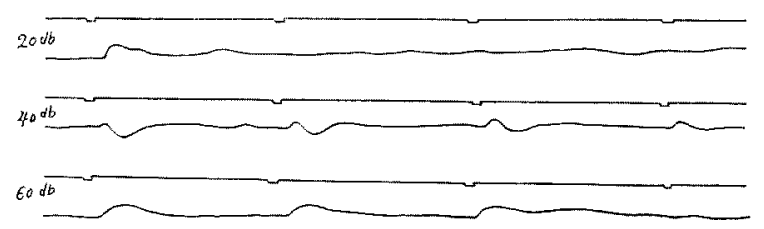

第 4 表 実験 I-D

同 1 例に対して $1000 \mathrm{cps}, 80 \mathrm{db}$ 純竟の反復呈示の央 駼を3日間隔で4 回繰返した時の反応回数の推移

\begin{tabular}{|c|c|c|c|c|c|}
\hline $\begin{array}{c}\text { 害駼 } \\
\text { 被检例 }\end{array}$ & 回数 & 第 1 回 & 第 2 回 & 第 3 回 & 第 4 回 \\
\hline No. & 1 & 7回 & 2回 & 1 回 & 2回 \\
\hline$"$ & 2 & 0 & 0 & 1 & 1 \\
\hline " & 3 & 1 & 3 & 2 & 6 \\
\hline$"$ & 4 & 8 & 6 & 2 & 2 \\
\hline " & 5 & 1 & 6 & 3 & 2 \\
\hline " & 6 & 2 & 0 & 1 & 0 \\
\hline " & 7 & 4 & 0 & 1 & 0 \\
\hline $\begin{array}{l}\text { 平垃 反 } \\
\text { 回 }\end{array}$ & $\begin{array}{l}\text { 応 } \\
\text { 数 }\end{array}$ & 3.3 & 2.4 & 1.6 & 1.9 \\
\hline
\end{tabular}

第 5 表 寒騟 II-A

「榆査音の閒えた回数を数之た」時の 反応閾俌之自筧閶值の差 (GSR 閶 傅一自筧閶倠) $1000 \mathrm{cps}$ 純音を使用

\begin{tabular}{|c|c|}
\hline 閵 攧 差 & 例 \\
\hline$-10 \mathrm{db}$ & 1 例 \\
\hline 0 & 5 \\
\hline+10 & 4 \\
\hline+20 & 0 \\
\hline+30 & 1 \\
\hline 総 例 数 & 11 \\
\hline $\pm 10 \mathrm{db}$ & $\begin{array}{c}10 \\
(90.9 \%)\end{array}$ \\
\hline
\end{tabular}

第6表 実 戨 I-B

検查啚について全く教示を与えずに $10 \mathrm{db}$ step 上界法で测定した場合の反応の

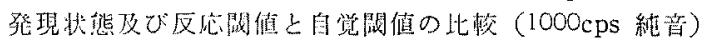

十：区応があつた埸合

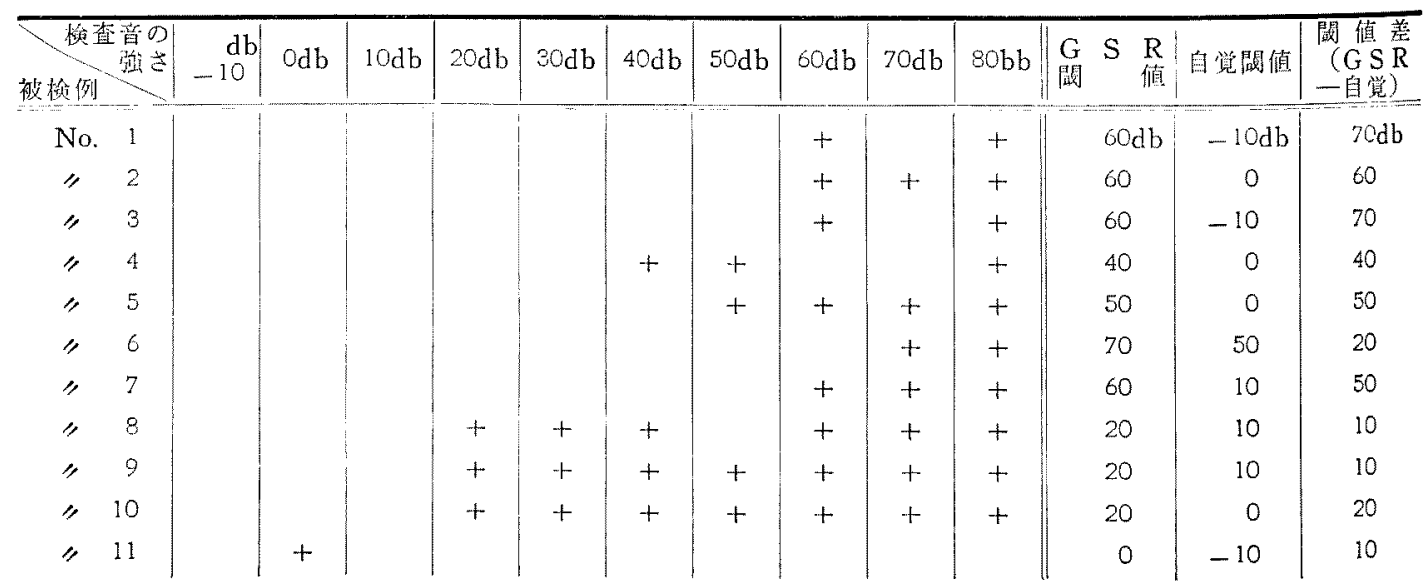

䦚值差去士10db以内にあるものは11 例中 3 例， $27.3 \%$ 


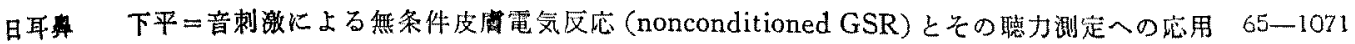

傾向を示している，しかし個々の例について見ると， 1 例と第 4 例以外では反応回数に上述の㖽向ぶなく不 則であつた。

\section{II. 音刺激に対する被検者の精神的負荷の有無と 反応閶值}

被榆例は A 群(䝿荷を与えた群)， B 群（無負荷の

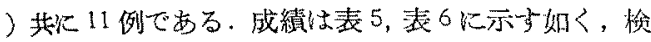
音の聞えた回数を数党させた A 群では大多数例が自

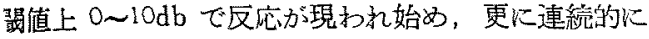
応が出現するのが認められた。しかし何等の教示も与 ないＢ群では反応䦪值は広く分散し，又反応は必ず

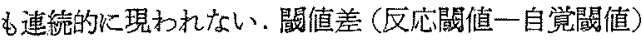
$10 \mathrm{db}$ 以内にあるものは A 群では11例中10例を占 るのに対して、B 群では11例中 3 例に過ぎなからた。 ち，無作為に上算法で音剌激を与えた場合の区芯閶值 自覚閾值と無関係に分散するが，音刺激に注意力を集 せしめるような精神的貪荷を被険者に与えた場合は， 覚閶值附近の弱、音刺激に対しても反応は非常に出易 なる事索示した。

\section{III. nonconditioned GSR audiometry}

成人及び小晃の合計 71 例に対して 1 人 1 耳について 查を施行した。との中 4 検査音に詨して全く反広しな もの及び基線の動摇が激し々测定不能のものが 12 例 つた，又検査の中途で，順応や自発性反応の頻発等の わに 4 检査音の中 1 . 2 音の測定が不能となつた例む 干あつた。

\section{A. 成人正常聴力例}

被検例 29 例中全く反応を示さぬ6 例を除き，23例に して㡈力を湘定した，その中 1 例は $1000 \mathrm{cps}$ の测定 能であつた。その成續は表 7 に示す如く閭值差 (GSR

\section{第 7 表 实跧 $\mathbb{U}$-A}

成人正常群の自・他覚的聴力测定の成績

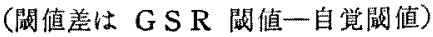

\begin{tabular}{c|c|c|c|c}
\hline 周波数 & $500 \mathrm{cps}$ & $1000 \mathrm{cps}$ & $2000 \mathrm{cps}$ & $4000 \mathrm{cps}$ \\
\hline$-10 \mathrm{db}$ & 0 & 1 & 0 & 0 \\
0 & 7 & 12 & 16 & 15 \\
+10 & 14 & 8 & 6 & 7 \\
+20 & 1 & 1 & 0 & 1 \\
+30 & 1 & 0 & 1 & 0 \\
\hline \multirow{3}{*}{ 例 } & 23 & 22 & 23 & 23 \\
\hline $\pm 10 \mathrm{db}$ & $91.3 \%$ & $95.5 \%$ & $95.7 \%$ & $95.7 \%$ \\
\hline
\end{tabular}

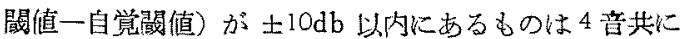
$90 \%$ 以上步占右。

B. 成人雏聠例

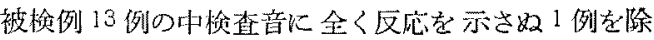
さ，残りの12例に対して測定を行つた。この群の難

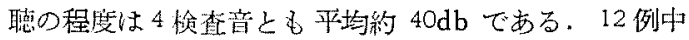
$2000 \mathrm{cps}$ の文浿定不能が 1 例， $500 \mathrm{cps}, 1000 \mathrm{cps}$ の测定 不能が 1 例，更に $500 \mathrm{cps}$ と $4000 \mathrm{cps}$ の測定不能が 1 例 あり，4音全部測定できたのは9例である，との成績 は表8に示李如く閶值差が 士10db以内にあるものは $2000 \mathrm{cps}$ の $81.8 \%$ で，他の3音ではいずれす $100 \%$ あった。

\section{C. 小胃正常德力例}

被検例 15 例の中測定不能の3 例学除く 12 例は4 音全 ての測定が可能であつた。この12例の年令は5才1カ 月乃至 9 才力月で, 平均7才9カ月である。测定不能 の3例中全く反応が現われは9才の1例を除いた2例は

第 8 表 実験 $[1]-B$

成人難聴群の自・他覚的聴力測定の成樍 (閶値差は GSR 閭値一自觉閵值)

\begin{tabular}{|c|c|c|c|c|}
\hline 咸值洷 & $500 \mathrm{cps}$ & $1000 \mathrm{cps}$ & $2000 \mathrm{cps}$ & $4000 \mathrm{cps}$ \\
\hline$-10 \mathrm{db}$ & 0 & 1 & 1 & 1 \\
\hline 0 & 7 & 7 & 7 & 8 \\
\hline+10 & 3 & 3 & 1 & 2 \\
\hline+20 & 0 & 0 & 2 & 0 \\
\hline+30 & 0 & 0 & 0 & 0 \\
\hline 総 例 数 & 10 & 11 & 11 & 11 \\
\hline $\pm 10 \mathrm{db}$ & $100 \%$ & $100 \%$ & $81.8 \%$ & $100 \%$ \\
\hline
\end{tabular}

第 9 表 実験 $\mathbb{I I}-\mathrm{C}$

小先正常群 (平均年令 719 力) $の$

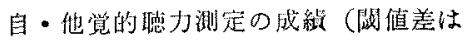

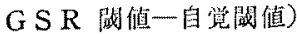

\begin{tabular}{|c|c|c|c|c|}
\hline 間波数 & $500 \mathrm{cps}$ & $1000 \mathrm{cps}$ & $2000 \mathrm{cps}$ & $4000 \mathrm{cps}$ \\
\hline$-10 \mathrm{db}$ & 0 & 2 & 0 & 2 \\
\hline 0 & 7 & 6 & 6 & 4 \\
\hline$+\quad 10$ & 4 & 2 & 5 & 4 \\
\hline+20 & 0 & 2 & 1 & 1 \\
\hline+30 & 1 & 0 & 0 & 1 \\
\hline 䋓 例 数 & 12 & 12 & 12 & 12 \\
\hline 土 $10 \mathrm{db}$ & $91.7 \%$ & $83.3 \%$ & $91.7 \%$ & $83.3 \%$ \\
\hline
\end{tabular}


共见 4 才台であつて, 基線の動摇や自発性反心の出現が 著しく，時間美か子て種々手段を尽したが測定不能であ つた。検查成䌙は表9に示声如く，閾值差が士10db以 内にあるものは $500 \mathrm{cps}$ と $2000 \mathrm{cps} て ゙ は 91.7 \%$, 残り の2音では $83.3 \%$ であつた。

\section{D. 小巟高度難眭例}

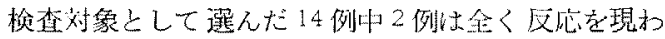
さず，12例に対して測定を行つた。そ年年は 6 才3

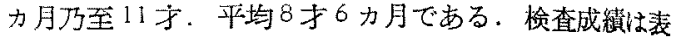
10，11に示したが，本検㭗に用いたオージオメーターの 最高出力は 4 音とも $90 \mathrm{db}$ である故，自覚法文は GSR 法の測定に際し，90dbで心答又は反応のない場合は （一）と記した．耐法共に测定できた揚合の閖値差を見 ると, 士10db 以内にあるるのは 500 cps と $1000 \mathrm{cps}$ で は 100\%, 2000 cps では $88.9 \%, 4000 \mathrm{cps}$ では $87.5 \%$ で あつた。

第 10 表 实 験 $\mathbb{1 I - D}$

高度難聴児啡の聴力测定成縝

\begin{tabular}{|c|c|c|c|c|c|c|c|c|c|c|c|}
\hline \multirow{2}{*}{$\begin{array}{l}\text { 被 } \\
\text { 教 } \\
\text { 例 }\end{array}$} & \multirow{2}{*}{ 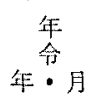 } & \multirow{2}{*}{ 性 } & \multirow{2}{*}{ 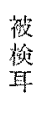 } & \multicolumn{2}{|c|}{$500 \mathrm{cps}$} & \multicolumn{2}{|c|}{$1000 \mathrm{cps}$} & \multicolumn{2}{|c|}{$2000 \mathrm{cps}$} & \multicolumn{2}{|c|}{$4000 \mathrm{cps}$} \\
\hline & & & & G S R & $\mathrm{S}$ & G S R & $\mathrm{s}$ & G S R & $\mathrm{S}$ & G S R & $\mathrm{S}$ \\
\hline 1 & $6 \cdot 5$ & 具 & 有 & $80 \mathrm{db}$ & $80 \mathrm{db}$ & $70 \mathrm{db}$ & $70 \mathrm{db}$ & $60 \mathrm{db}$ & $80 \mathrm{db}$ & $50 \mathrm{db}$ & $70 \mathrm{db}$ \\
\hline 2 & $6 \cdot 3$ & 女 & 右 & 90 & 90 & 80 & 80 & 80 & 70 & 80 & 70 \\
\hline 3 & $8 \cdot 0$ & 女 & 右 & 80 & 80 & 80 & 80 & 70 & 80 & 70 & 70 \\
\hline 4 & $7 \cdot 10$ & 男 & 有 & 90 & 90 & $(-)$ & 90 & $(-)$ & 80 & $(-)$ & 70 \\
\hline 5 & $8 \cdot 8$ & 女 & t & $(-)$ & 80 & 90 & 80 & $(-)$ & 90 & $(-)$ & 90 \\
\hline 6 & $8 \cdot 3$ & 女 & 右 & 90 & 80 & $(-)$ & 90 & $(-)$ & $(-)$ & $(-)$ & $(-)$ \\
\hline 7 & $7 \cdot 10$ & 女 & 左 & 70 & 70 & 70 & 70 & 80 & 90 & 70 & 70 \\
\hline 8 & $10 \cdot 1$ & 男 & 右 & 90 & 90 & $(-)$ & $(-)$ & 90 & 90 & 80 & 80 \\
\hline 9 & $10 \cdot 5$ & 女 & 左 & 90 & 80 & $(-)$ & $(-)$ & 80 & 90 & 80 & 70 \\
\hline 10 & $9 \cdot 10$ & 男 & 左 & 90 & 80 & 80 & 90 & 90 & 90 & 80 & 80 \\
\hline 11 & $11 \cdot 0$ & 男 & 左 & 80 & 70 & 80 & 90 & 90 & 90 & $(-)$ & $(-)$ \\
\hline 12 & $7 \cdot 6$ & 女 & 右 & 80 & 70 & 80 & 80 & 80 & 80 & 80 & 80 \\
\hline
\end{tabular}

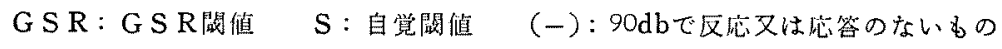

第 11 表 笑験 $\mathbb{1 1}-\mathrm{D}$

高废蜼聴涀群（平均年令 8 才 6 力月）の

自・他觉的滤力测定の成程

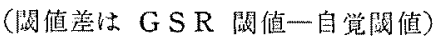

\begin{tabular}{|c|c|c|c|c|}
\hline 周没数 & $500 \mathrm{cps}$ & $1000 \mathrm{cps}$ & $2000 \mathrm{cps}$ & $4000 \mathrm{cps}$ \\
\hline$-20 \mathrm{db}$ & 0 & 0 & 1 & 1 \\
\hline$-\quad 10$ & 0 & 2 & 3 & 0 \\
\hline 0 & 6 & 6 & 4 & 4 \\
\hline+10 & 5 & 0 & 1 & 3 \\
\hline+20 & 0 & 0 & 0 & 0 \\
\hline 総 佨 数 & 11 & 8 & 9 & 8 \\
\hline $\pm 10 \mathrm{db}$ & $100 \%$ & $100 \%$ & $88.9 \%$ & $87.5 \%$ \\
\hline
\end{tabular}

I. GSR について

第5章 考按

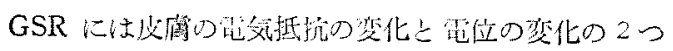

があり、これ等の現象の発見者又は紹介者の名前に因儿 で，前者をFéré の效果文はＶeraguth の效果，後者 をTarchanoff の効果之呼び，文測定する克場より前者

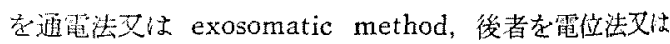
endosomatic method 之屯云526) 30).

電位法はこの反応が微弱で，測定には複雑な装置を必 要とした敌，從将 GSR の研觉の大部分は通電法によ つて行われてきた。しかし最近電子工栄の発迲により高 性能で安定な增幅器の製作が容易になり，文記録にもへ

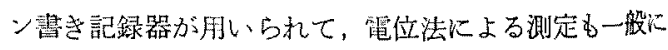
広く行秃れるようになつた。

通䉓法ではその反応曲線は単暞性ではあるが，反応量

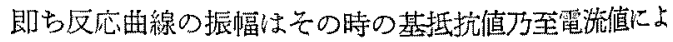
つて左右されるので，振幅を単に長さの単位とか電気抵 抗に拈けるオ一ムの単位で表わしても一船性がなく，こ

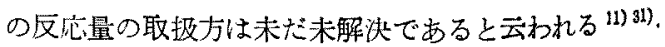




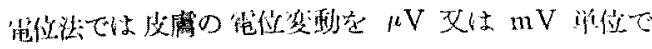

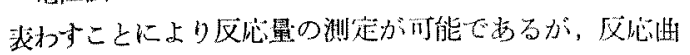

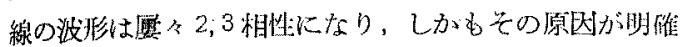

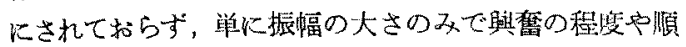
位を決定する事ができない，電位法による波形の変化と その要因については，我国に推いて子近藤 ${ }^{19}$ ，横田 ${ }^{41)}$ ， 高木 ${ }^{36)}$ ，高橋 ${ }^{35)}$ 等の㽗究があるが，こつではこの問题 について融れないことにする。

II. nonconditioned GSR audiometry について 心理学あるい性理学の分野炕括ける GSR の研究 には，音刺激は古くから使用されてきたが，他覚的聴力 测定の立場から本現瑙を利用しょうとした人としては先 ずAlbrecht 1)（1918）を挙げねばならね。彼は刺激音 として咡語を用いて通電法に上り測定を行つた。即ち正 常人は $4 \mathrm{~m}$ の距離で咡語刺激に明確な反応を示し, 難 聴者では本反応の閾值と自覚閾値がかなり正確に一致す る事を明らかにした、文器質性瞳は全く反応を示さず，

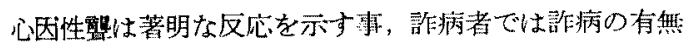
のみならずとの聴力の程度むかなり精然に知る事ができ たと述べた、van Iterson ${ }^{28)}$ (1920) b器質性難:㯖中機 能性難聴又は詐病に対する他覚的检査法として本反応を 利用し，刺激としては咡語、会話音、ガルトン笛、爆発 音を用いた。攵の結果正常者は $6 \mathrm{~m}$ の距離で low voice に反応し，詐病者では“I am goiug to hurt you.”な る四語で反応を得たと云うその後 Michels \& Randt 27) (1947) 6器質性難聴之心西性蜼聴之の鑑別に本法を 応用した，検査音には音丑及びオージオータ一純音亚 びに話声を用いて良好な結果を得たが，維音（1024cps 及び $2048 \mathrm{cps})$ に対しては 50db 以下の強さでは反応が 出にく子，明確な反応を得るには60db以上の强さが 必要であつたと述べている，更に Knapp \& Gold 20) (1950) も同様な目的に本法を用い，椧查音として“Can

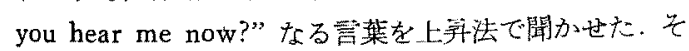
の結果被检者 121 例中の $88 \%$ は音䟝激が critical intensity 飞逢すると明らかな反応を示し，灭正常者 14 例 及び器質性歏聴者 26 例計 40 例中 5 例を除いた残りの全

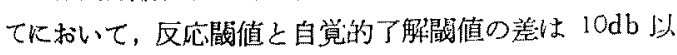
内にあるが，心因性難㯖者てはこの差は大きからたと報 告している。 㕛 Maspétiol (4)（1953）は不快感発現強 度閶 (uncomfortable Loudness Level, ULL) 内外の 強さの純音汇対する GSR の発現状態を钼察し，GSR

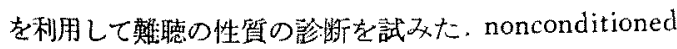

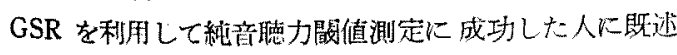

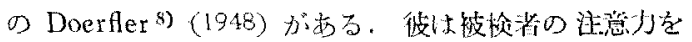

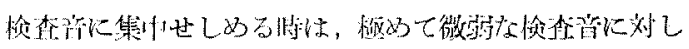

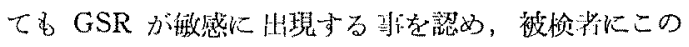
ような精神的繁張を促寸手段として，音を与克る前に一 旦警告灯を点し，これが消えてから8 秒以内に検查音を 与えるようにした，かくして上舁法により測定を行い，

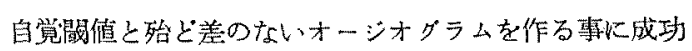
した．しかし嗦は多数例についての成綨は発表していな い. Grisanti 14) (1958) 6成人 18 人に刘して 128eps 上り $8192 \mathrm{cps}$ 红亘る 8 音の反応閾値と自覚閾值を求め,

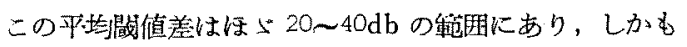
低音より高音になる程闒值差が大になると報告してい る。

\section{III. 反応発現のための音剌激の条件}

GSR は此較的非特異的な現象であり，種ふの㓩激に より誘発される汗腺活動による反応であるが，音刺邀は 電気刺激々〉もにその新激の強さを量的に簡単に表わし 得る所から脤々利用されてきた。ところで音刺激により GSR が発現する際は，光に対する瞳孔反射の如く被椧 者の心理的伸介なしに反応が出現するのであろらか．古 閑21)によると，睡䟨中でも音剩激による GSR の発生 が見られるが，反応発生部位の骤位性は筧睲時の夫と瑁 るとのことである。しかし覚睲時には一般に音刺激が被 検者にかなり強い感覚をひき括こす時にの及反応を生ず ると云和れる、van Iterson ${ }^{39)}$ によれば本現象は reflex of hearing ではなくて, reflex of affectであると云う. 音刺激が被検者に与える心理的刺激訤果について，Pet. erson ${ }^{32)}$ やWechsler ${ }^{39)}$ は affective な影響とか感情 的動摇を等ら重視した，これに対して Darrow ${ }^{6}$ )

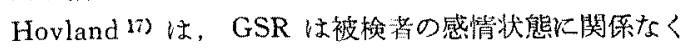
直接的，反射的に excitation に続いて現われるのであ り，この点から GSRは生体の比較的簡単な反射活動の らであると見做して括り，Landis \& Dewick ${ }^{22)}$ む同 様な説を迹べている。い寸゙れにせよ GSR は音新激に よる直接反沁でけなく，被检者の心的仲介を経て生ずる 事比異論はない。

種々な音制被の中で純音山最む単純で刺激効果に之し い事憺を续ため。故に予め何等の工作なしに無条件刺 激として純音を用いて GSR を発現せしめるには，一 般にある程度以上の強さを必要とする。. Maspétiol 26)， Faure \&Portman ${ }^{9)}$, Michels \& Randt ${ }^{27)}$ 等の記城を

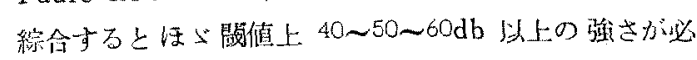

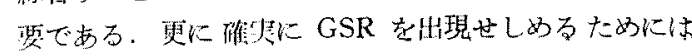




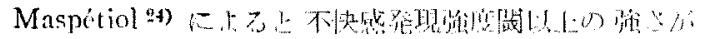

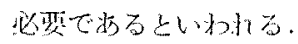

\section{IV. 純音剌激と牘応}

GSR の测定に当つて制激を反復呈示与る㭙に現和れ る反応の潮減, 消滅は, 㴬減現象又は溜応 (diminution

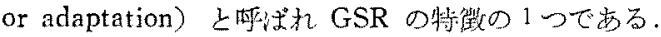

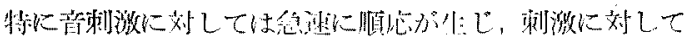

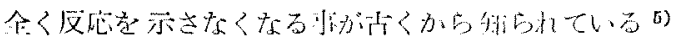

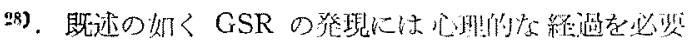

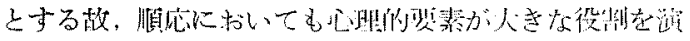

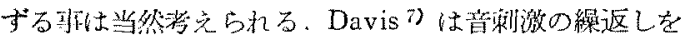

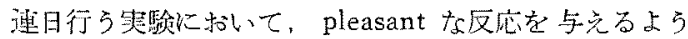
な剌激に対しては GSR は增強し，unpleasant な反応

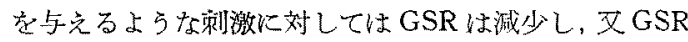
が減少するよ5な梙激は比較的単純なるのであると云り

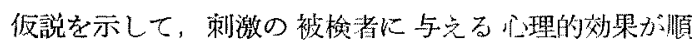
応に対して大きな影留力を持つ事を強調している。Co-

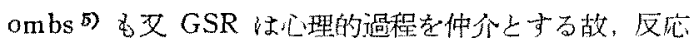

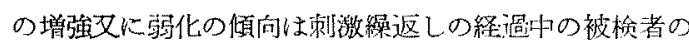
心理的調整のいかんによると述べている。

以下私の来騟に执いて钼察された音刺激に対する順広 について考察を進める。

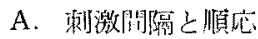

GSR 測定時の刺激呈示の待間的關隔に閔し测定部位

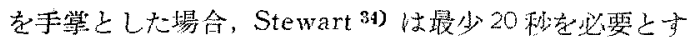

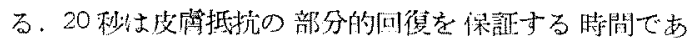

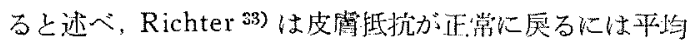
15 秒を要するとしている。こ狆等は通笔法の場命であ

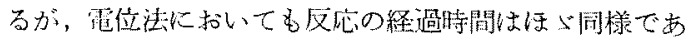

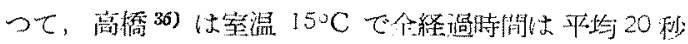
であつたと述へている，更に Coombs 5) は同一音刺晸

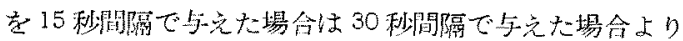

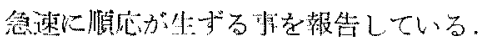

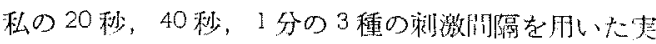

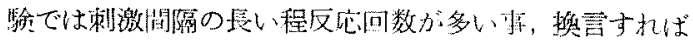

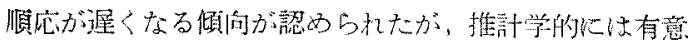
赫が見られなかりた。

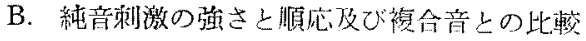
既に述べた如く，純音に上り GSR を生ずるたるには 一般に䦪值上 $40 \sim 60 \mathrm{db}$ 以上の強さが必要で古吕と云わ

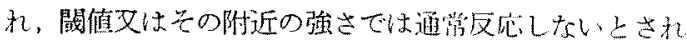
ている.しかし例外的に闌值附近の強さの純音比刘して も反店した例の部諓 ${ }^{82}$ 23)13) るあるが，多数例について

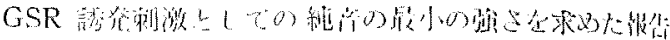

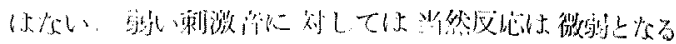

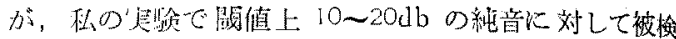

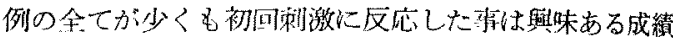
と思われる。こ狆は測定器の性能にもよるが，後述の加

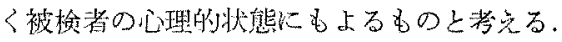

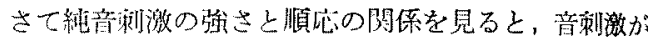

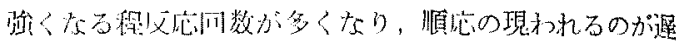

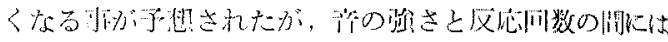
一定の㑯问が梁められなかつた。即る闖值上 $80 \mathrm{db}$ 以

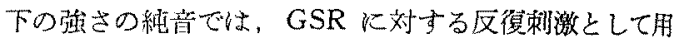
いる時，被检者に与无る刺激効果の減衰の程度には強さ による差がない事を推祭させる。

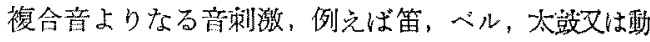

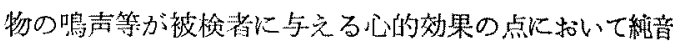
より遦かに勝れている事は明かであり，これ等の複合音 刺激に対する順応の発現が純密の場合に比して革い專も 当然予想される。私の牛の鳴声の擬音を用いた実験て注 平均反応回数は 6.6 回で，純音 $(1000 \mathrm{cps})$ を同一条件で 与えた際の平均反応回数 2.9 回に比べて遥かに順仙の琴 われ方の逮い事がわかつた。

C. 同一純音制激の絓日的繰返しに対多る反応の 溜骎

Davisうは同一刺激を1日1回宛见5日間与え,これ に刘する GSR の大きさの推移を調べた結果，1000 cps 純音の强大音（正確な强さは不明）を用いた場合は反忘

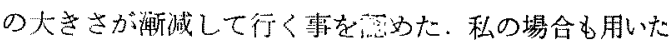
音剩激は $1000 \mathrm{cps}$ 純音であるが，測定に当つては反応 の大きさを目䅺とせず，反応回数の推移を調へ，且実影 日の間隔も3日とした教 Davis の成績と同一に論ずる

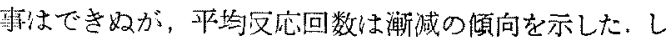
か乙個々の被检例についてみると，反应回数の消長の不 梘則のものが多く，この結果から名純音に対する non-

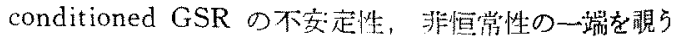
事ができる。

\section{V. 被検者の精神的負荷と反芯間値}

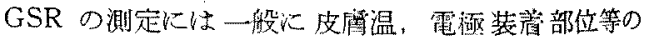

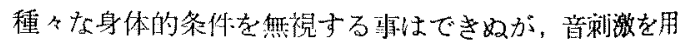

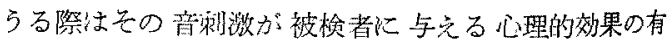
無，大小が測定結果に大きな影留:与える事に対しては

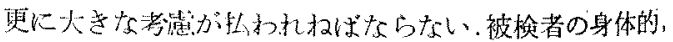

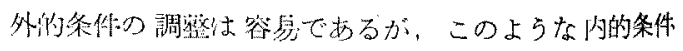
の淍整は必ずしも容忽ではなくここに純音剌激による 


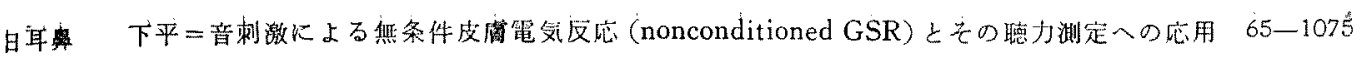

nonconditioned GSR の不安定性の最大の原团があ る。この反灾の不安定性については，順心以開与る私

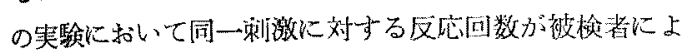
り変動の多い事，又同一被検者でも実期日により反応回 数が不規則に变動する事等からら知る事ができるが, 間 值下の強さから純音を10db step 上苏法で䦌かせせ場

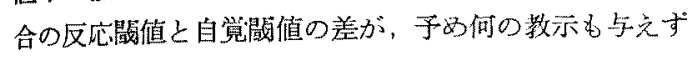
に無作為的に湘定した鸟雅 II-B 詳では 10〜70dbの

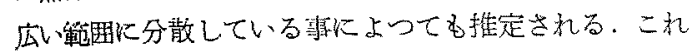
に反し「检查音の聴えた回数を数えよ」と教示した夷䜿

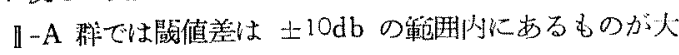
部分を占め，前者とは全く刘照的な結果を示し，又闌值

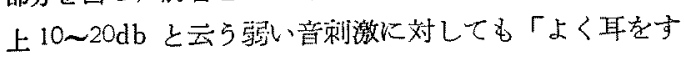
ませて聞えてくる音に注意せ上」との教示により被榆例 の全負が少くとも初回赖激に刘しては反应した（鼠駼

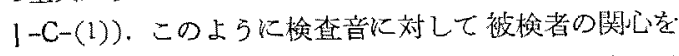
㬇起し，注意力を集中させる事により通常全く反応を示 さない上らな弱去刺㵀に対しても敏感に反応するように なる、この事実が nonconditioned GSR に上る維音聴 力测定の基整をなすのである。

\section{VI. 私の行つた nonconditioned GSR audiom-} etry

私の行つた nonconditioned GSR audiometryに拀い

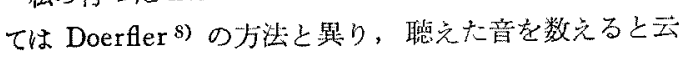

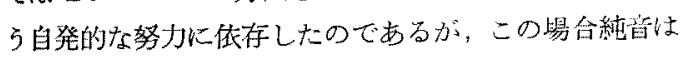

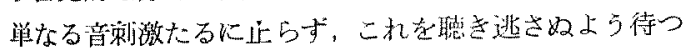
と云う篹張と, 数鿑ると云う精神的労作它促す+インと なる訳であつて，舞作為的に与えた場合上り被捡者に及

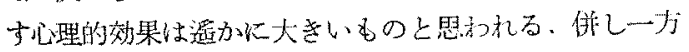

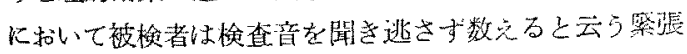

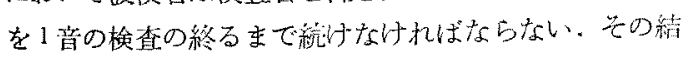
果生ずる被检者の疲学を防ぐために予め被唡者心刘して

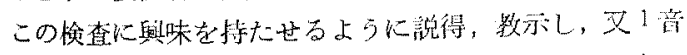

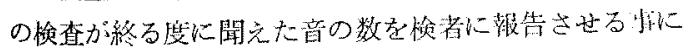

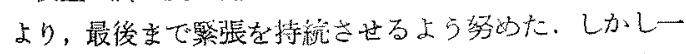

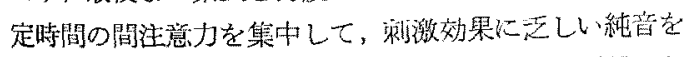

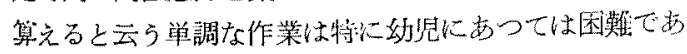

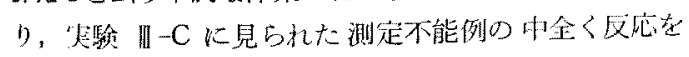

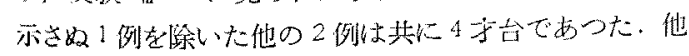

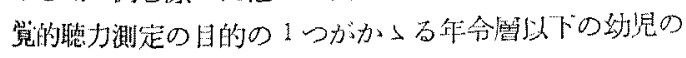

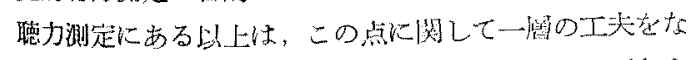

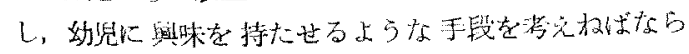
d2. conditioned GSR audiometry の湘定成场流炀諭 被梭者の年令が少くなる程低下゙劣るが，艺の数钓は㣮

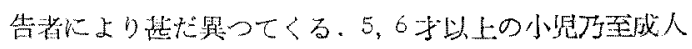

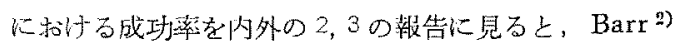

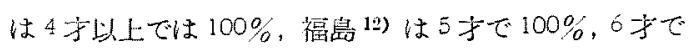
92.3\% 上云う度好な成績を得ているが，金谷 ${ }^{18)}$ は8

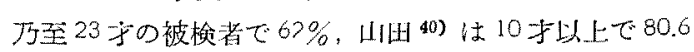
$\%$ の成績を発表している。私の場台は1例1耳，4畒の

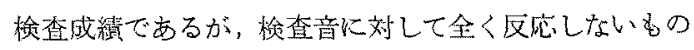
や，基線の不管定に上る測定不能例子含めて，全被检例 71 例中心測定不能例走 12 例 $(16.9 \%)$ で，部分们成功 例屯含めた全成功例は59例 $(83.1 \%)$ であつた。この 成績は上述の conditioned GSR audiometry に上る謨 家の成維に比して決して少るものではないか，测定不拕 例が传 学当。

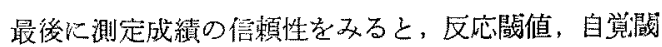
值ともに $10 \mathrm{db}$ step 上笔法で測定したが，成人群と小

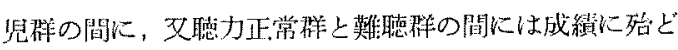

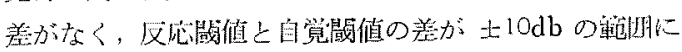

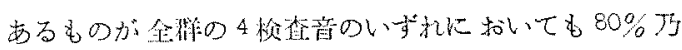

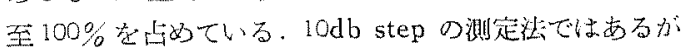
この成績は今日运垠告されている conditioned GSR audiometry の諸成績に比して澺色ない成續であると思 う、特に小見の高度難聴群では会話が不可能のため, 附 深の教的を通してて測定法を説明しなければならず，測定

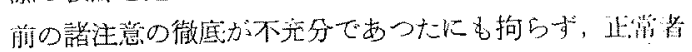
に比べて都明な反応を示吉例が多く兒受けられた。この

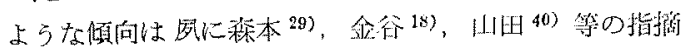

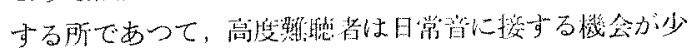

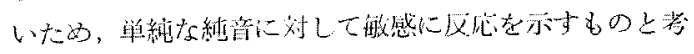
える。

\section{第 6 章 結語}

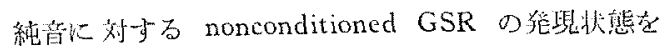

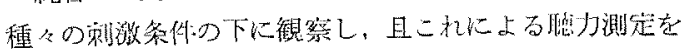
試み下記の絬馀を得た。

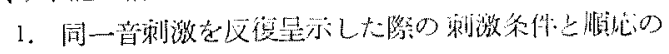
挦係

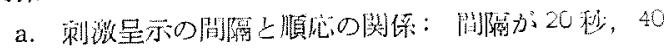

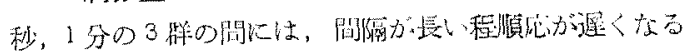

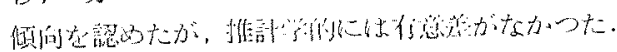

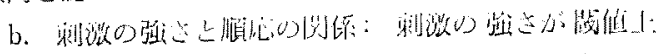
$10 \sim 20 \mathrm{db}, 30 \sim 40 \mathrm{db}, 50 \sim 60 \mathrm{db}$ 及び $80 \mathrm{db} 04$ 群では, 


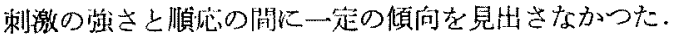

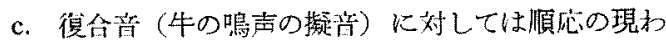

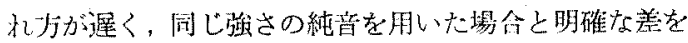
施めた。

2, 热作為的に与えた純穴に刘する反応出現の状態 は，個人差が大きく且同１例でも实領日により基る等甚 た不穴芫であるが，检查音比刘して被检者の注意力を集

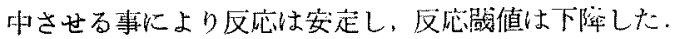

3.「檢查音の聞えた回数を数光させる」坓により検查 音に対して被検者の注意力を第中させて，500cps，1000 cps, $2000 \mathrm{cps}, 4000 \mathrm{cps}$ の 4 音比つて $10 \mathrm{db}$ step 上型

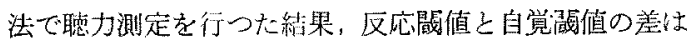

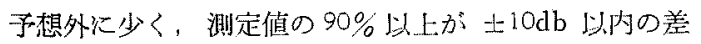
に步つた.

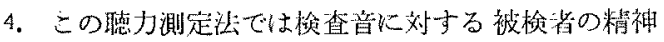
的祭掁を長く保たせる雅は困難な場合が多く，成人でも 1 回の測定としては1耳，4音の蚞查が限度と考えられ，

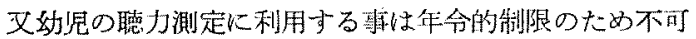
能であつた。

\section{参考文献}

1) Albrecht, $W$.: Die Trennung der nicht organischen von der organischen Hörstörung mit Hilfe des psychogalvanisches Reflex, Arch. Ohren-usw. 101, 1, 1918. 2) Barr, B.: Pure tone audiometry for preschool children. A clinical study with particular reference to children with severely impaired hearing, Acta oto-laryng. Suppl. 121, 1955. 3) Bordley, J.E., Hardy, W.G. \& Richter, C.P.: Audiometry with the use of galvanic skin-resistance response, A preliminary report, Jo hns Hopk. Hosp. 82, 569, 1948, 4) Bordley, J.E. \& Hardy, W.G.: $\Lambda$ study in objective audiometry with the use of psychogalvanometric response, Ann. Otol. 58, 751, 1949. 5) Coombs, C.H.: Adaptation of galvanic response to auditory stimuli J. Exp. psychol. 22, 244, 1938. 6) Darrow, F.: 交献 17)より可月.

7) Davis, R.C.: Modification of the galvanic reflex by daily repitition of a stimulus, J. Exp. Psychol. 17, 504, 1934, 8) Doerfler, L.G.: Neurophysiological clues to auditory acuity, J. Speech Hear. Dis. 13, 227, 1948, 9) Faure, J., Portmann, M., Dutertre, F.\& Bramerie, $R .:$ Au sujet de l'audiométrie realisée à l'aide du réflexe psychogalvanique, Rev.
Laryng. 73, 66, 1952. 10) Féré, C.: Note sur des modifications de la résistance électrique sous l'influ. ences des excitations sensorielles et des émotions, C.R. Soc. Biol. Paris 40, 217, 1888, 11) 鄁格閒一:

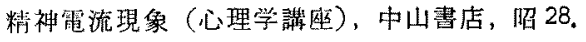

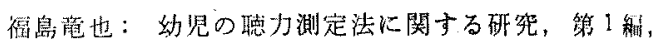
PGSR-audiometry，日耳率，63，1847。昭 35 .

Goldstein, R., Ludwig, H. \& Naunton, R.F.: Diffculty in conditioning galvanic skin responses: its possible significance in clinical audiometry, Acta oto-laryng. 44, 67, 1954. 14) Grisanti, G.: Sul valore della soglia uditiva ricercata mediante il riflesso psicogalvanico semplice, Udito-Voce-Palora 1, Fasc. 2, 1958, 15) Hardy, W.G. \& Bordley, J.E.: Special technigues in testing the hearing of children, J. Speech Hear. Dis. 16, 122, 1951 . 16) $\mathrm{Ha}$ $r d y$, W.G. \& Bordley, J.E.: Evaluation of hearing in young children, Acta oto-laryng. 40, 346, 1952. 17) Hovland, C.I. \& Riesen, A.H.: Magnstude of galvanic and vasomotor response as a function of stimulus intensity, J. Gen. Psychol, 23, 103, 1940.

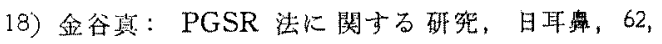

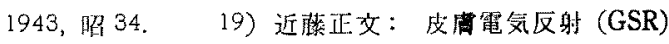
に括方電位法之通電法の比較, 北海道医学雑彭, 32 ; 373, 炤 32, 20) Knapp, P.H. \& Gold, B.H.: The galvanic skin response and diagnosis of hearing disorders, Psychosomatic Med. 12, 6, 1950.21 2)

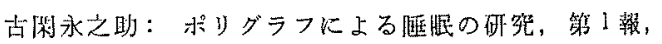

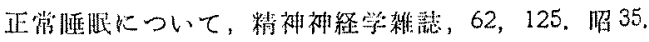

22) Landis, C. \& Dervick, H.N.: 文献17)上り可月. 23) Lehrhoff, I. \& Hills, B.: An experimental study of auditory threshold acuity in children with cerevral palsy by PGSR and other techniques, Ann. Otol. 67, 643, 1958. 24) Maspétiol, R., Pigement, M. \& Tronche, R.: Le seuil auditif inconfortable. Sa recherche par le réflexe psychogalvanique. Son intérêt clinigue, Ann. d' Oto-laryng. 70, 388, 1953. 25) Maspétiol, R. Pigement, M. \& Tronche, R.: L' évalution et les enseignements de l'audiométrie objective par étude du réflexe psychiatre, Ann. d' Oto-laryng. $72,266,1955 . \quad$ 26) McCleary, R.A.: The nature of the galvanic skin response, Psycholog, Bull. 47, 97, 1950 .

27) Michels, M.W. \& Randt, 


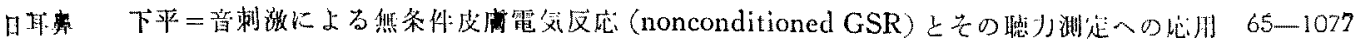

C.T.: Galvanic skin response in the differential diagnosis of deafness, Arch. Otolaryng. 45, 302, 1947. 28) Misbach, L.E.: Effect of pitch of tone stimuli upon body resistance and cardiovascular phenomena, J. Exp. Psychol. 15, 167, 1932. 29) 森

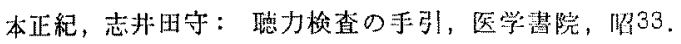

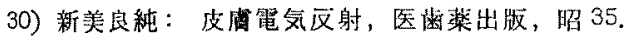

31）大坪萃彦：皮虚電気反射の定量的梌查法について， 第1, 編，皮庴電気反射の一般的性質，医撩，8，13， 29. 32) Peterson, F.: 文献 17) より引用。 33) Richter, C.P.: 文献 15) 上り引用. 34) Stewart, $K . C$. : Some basic considerations in applying the GSR technique to the measurement of auditory sensitivity, J. Speech Hear. Dis. 19, 175, 1954. 35)

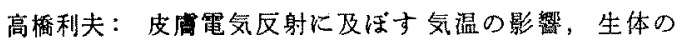
科学, 8, 177, 昭 32. 36) 高木健太郎, 中山炤婎: GSR の波形について，日本生理学雑誌，20，341。昭33.
37) Tarchanoff, J.: Über die galvanischen Erscheinungen in der Haut des Menschen bei Reizungen der Sinnesorgane und bei verschiedenen Formen der psychischen Tätigkeit, Pflügers Arch. f.d. ges. Physiol. 46, 46, $1890 . \quad 38$ ) van Iterson, C.J.A.:

Psychic-galvanic-reflex-phenomenon in ear examination, Acta oto-laryng. 2, 174, 1920. 39) Wechselr, D.: 文献 17) 占り引用. 40) 14日恒蜼: Psychogalvanic Skin Response に上万他觉的㯖力椮查法につい

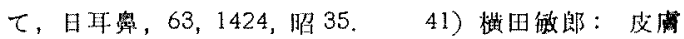

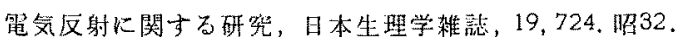

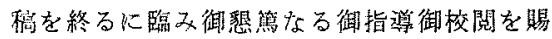

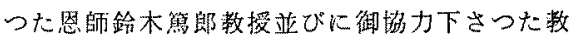
室員諸见に染甚なる謝意を表す

（原穱到䈐＝昭和 37.4 .18 日） 